\title{
Dez ideias sobre Abbas Kiarostami ${ }^{1}$
}

\author{
Jansen Hinkel' \\ https://orcid.org/0000-0002-3628-424X \\ I - Universidade Anhembi Morumbi. \\ São Paulo (SP). Brasil.
}

Resumo: $\mathrm{O}$ artigo apresenta dez pensamentos teóricos escolhidos para abordar a obra cinematográfica do diretor iraniano Abbas Kiarostami. A partir da análise do filme Dez, lançado em 2002, e de outras realizações do cineasta, são discutidas noções epistemológicas presentes nos espaços urbanos, representadas pela técnica do cinema. Para o texto, foram eleitos os seguintes campos de discussão confluentes entre os filmes e suas propostas estéticas, inseridos no estudo da comunicação audiovisual: o espaço, o real, o lugar, a crítica social, o enquadramento, a fala, o meio, o deslocamento, a natureza social e o confinamento.

Palavras-chave: Abbas Kiarostami; cinema iraniano; confinamento; espaço social.

Abstract: Ten ideas about Abbas Kiarostami - The paper presents ten theoretical thoughts selected in the cinematographic work of Iranian director Abbas Kiarostami. Based on analysis of the film Ten, released in 2002, and some of the filmmaker's other achievements, the paper discusses epistemological notions present in urban spaces and represented by the technique of cinema (are discussed). Inserted in the study of audiovisual communication, the following discussion fields were recognized in their convergence between distinct films and their aesthetic proposals: space, reality, place, social criticism, framing, speech, environment, displacement, social nature and confinement.

Keywords: Abbas Kiarostami; Iranian cinema; confinement; social space.

1 Parte do artigo aqui proposto utiliza conceitos apresentados na dissertação de mestrado intitulada "Os Espaços De Confinamento No Cinema Persa", de minha autoria. Para esse texto, portanto, algumas das ideias sobre o cineasta Abbas Kiarostami foram desenvolvidas a partir da dissertação citada, mas agora com uma nova abordagem, considerando a pesquisa realizada a respeito do cinema do Oriente Médio. 
Aos olhos dos pássaros o Ocidente é onde o sol se põe e o Oriente onde o sol nasce, apenas isso

Abbas Kiarostami

\section{O espaço}

As narrativas cinematográficas dependem de um espaço de ação. Tal espaço pode se estabelecer pelo deslocamento (em que as paisagens e as andanças dos personagens compõem a história contada), ou através do confinamento, quando por uma delimitação geográfica a narrativa se encerra num único lugar. Por vezes, esses dois procedimentos se juntam para que ocorra a ficção ou o documentário. É o caso de filmes onde o espaço, a priori, em locação única, faz da mesma uma locação em movimento.

Por exemplo, filmes cujo cenário é um avião, ou um automóvel, são, obviamente, locações em movimento (ou construídos para tal impressão, no caso de gravações em estúdio que falseiam o movimento). Entretanto, nesse movimento, há também a trama ali confinada: o espaço se move, mas a narrativa se dá num espaço único e fechado.

O espaço, para o cinema, é a materialidade em que o tempo se costura, ou seja, construir uma história é eleger um lugar e esculpir a partir dele a passagem do tempo através dos planos e da encenação que Ihe conferem o ritmo. Um filme é uma relação de invenção entre tempo e espaço. O espaço, então, é o lugar do cinema: tanto em relação à imagem quanto ao cinema como dispositivo.

Na experiência, o significado de espaço frequentemente se funde com o de lugar. "Espaço" é mais abstrato do que "lugar". O que começa como espaço indiferenciado transforma-se em lugar à medida que o conhecemos melhor e o dotamos de valor. Os arquitetos falam sobre as qualidades espaciais do lugar; podem igualmente falar das qualidades locacionais do espaço. As ideias de "espaço" e lugar não podem ser definidas uma sem a outra. A partir da segurança e estabilidade do lugar estamos cientes da amplidão, da liberdade e da ameaça do espaço, e vice- versa. Além disso, se pensamos no espaço como algo que permite movimento, então o lugar é pausa; cada pausa no movimento torna possível que localização se transforme em lugar. (TUAN, 1983, p. 6). 
A partir dessas reflexões a respeito de espaço e lugar, o presente texto admite as imbricações de ambos os termos, mais ou menos de forma inversa. Para o geógrafo Yi-Fu Tuan, espaço é amplidão e movimento, ao passo que lugar é algo mais particularizado, em relação à localização, e tais definições foram pensadas no sentido da experiência humana; a ideia aqui, mesmo considerando as acepções do geógrafo, é entender o espaço como aquilo que o dispositivo captura e que está presente na projeção. Já lugar é a potencialidade desse espaço idealizado pelo cinema, aquilo que imaginamos e construímos mentalmente, mesmo sem ver ou ouvir, o que não é exatamente fora de campo (próprio da estética cinematográfica), e sim o lugar no sentido social.

Em Dez (filme lançado em 2002) o espaço é o carro em movimento (aquilo que vemos e ouvimos). O lugar é a capital Teerã, pela qual o carro passeia, mas ela não é descrita através de planos; assim, o lugar é aquilo que construímos mentalmente através do dialogismo das personagens, e apenas o imaginamos quando somos influenciados pelo ponto de vista dessas personagens a respeito da vida na cidade. Já em Shirin (filme lançado em 2008), a operação entre espaço e lugar se dá pela sala de cinema, que é o espaço em que o filme se passa: várias mulheres assistem a um filme no cinema, e cabe ao espectador imaginar esse cinema (lugar), visto que o espaço (o que vemos e ouvimos) é apenas um público assistindo à projeção, e nós, como espectadores, temos o ponto de vista da tela, como que do filme que se mostra às personagens. Ou seja, é um filme sobre pessoas assistindo a um filme, e nós percebemos esses telespectadores.

Tais obstruções espaciais servem para que o cineasta Abbas Kiarostami discuta seu país e sua sociedade, ao articular relatos numa única célula espacial para cada filme: um automóvel em movimento e uma sala escura com espectadores que assistem a uma projeção. Agora, determinados os espaços em Dez e Shirin, antes de se se pensar numa conceituação para o lugar desses espaços, é preciso entender a realidade desse lugar.

\section{O real}

De todas as formas de arte, o cinema é a expressão que mais valoriza e persegue a ideia de realidade e a estética do realismo, - mesmo com as vanguardas do início do século XX, durante o primeiro cinema, com anarquia produtiva antes de se cristalizar o dispositivo como sala escura (MACHADO, 2016) e de experimentalismos com a imagem e som, perceptíveis em obras 
de cineastas como Stan Brakhage, Chantal Akerman, Agnès Varda e JeanLuc Godard - , a qual se baseia, principalmente, na realidade e na intenção de captá-la.

O "realismo" dos materiais de expressão cinematográfica não passa do resultado de um enorme número de convenções e regras, que variam de acordo com as épocas e as culturas. [...] Ora, a cada etapa (mudo, preto e branco, colorido), o cinema não cessou de ser considerado realista. O realismo aparece, então, como um ganho de realidade em relação a um estado anterior do modo de representação. Esse ganho, porém, é infinitamente renovável, em consequência das inovações técnicas, mas também porque a própria realidade jamais é atingida. (AUMONT, 2012, p. 134-135).

As mudanças acontecidas no Oriente Médio a partir da década de 1970, e uma nova situação econômica e social instaurada no Irã após a queda da ditadura do Xá Mohammad Reza Pahlavi, causaram o recrudescimento de valores fundamentalistas na realidade do país. O cinema foi um dos primeiros campos atacados pelo novo regime teocrático. Essa nova realidade produziu filmes que apesar de estarem sob censura se interessaram em mostrar a sociedade iraniana com um realismo próprio. Abbas Kiarostami é um desses exemplos. Em Dez (2002), a vida das mulheres, e suas questões morais e íntimas, são colocadas num plano e contraplano fechado, dentro do automóvel, em que o real é representado de forma dialógica, enquanto as imagens da cidade se deslocam no vidro das janelas.

Pode-se entender o cinema iraniano através de duas realidades, ou duas ditaduras: a ditadura do Xá até 1979 e o regime teocrático que existe até hoje. No governo do Xá o cinema não podia ser político, nem criticar a dinastia Pahlavi ou a miséria do país. Contudo não havia censura moral, e nem a obrigatoriedade do véu para as mulheres. Assim, o que existia no cinema era o chamado filmfarsi².

Com o estabelecimento do regime teocrático, atentados aos cinemas (incendiados e bombardeados pelos representantes dos aiatolás por serem considerados lugares de perversão e ofensa a Deus), a produção de filmes

2 O filmfarsi foi um gênero de cinema popular, produzido durante a ditadura do Xá, inspirado no cinema hollywoodiano e no melodrama italiano, com teor erótico e cômico, ausência de crítica social e um olhar fetichista e machista em relação às mulheres. De forma genérica, pode-se dizer que o filmfarsi é o equivalente iraniano da pornochanchada brasileira da época da ditadura militar. O documentário Filmfarsi, dirigido pelo cineasta Ehsan Khoshbakht, presente no festival "É Tudo Verdade" de 2020, aborda a estética e a história desse gênero fílmico pré-Revolução. 
passou por um novo tipo de censura, com extremo controle do governo, o que fez nascer um outro cinema e uma outra realidade para o mesmo.

O Ministério da Cultura e Orientação Islâmica (MCOI) passa a avaliar qualquer projeto audiovisual feito no país; os princípios e procedimentos operacionais do cinema iraniano, organizados em forma de regulamento, possuem as seguintes proibições:

- qualquer insulto ao monoteísmo, aos profetas e aos imãs;

- qualquer insulto aos princípios que sustentam o governo islâmico no Irã (velayat-e faqih);

- qualquer insulto à polícia e às forças armadas;

- negar o papel da revolução na formulação das leis;

- negar a ressurreição e seu papel na evolução do Homem através de Deus;

- negar a continuidade do líder religioso (Emamat);

- negar o papel da República Islâmica do Irã sob a liderança de aiatolá Khomeini em livrar os muçulmanos do imperialismo do mundo;

- $\quad$ proibição de filmes que tratem de violência, sexo explícito, prostituição e corrupção;

- $\quad$ personagens negativos com barba (o que poderia ser associado com a religiosidade);

- contato físico ou piadas entre homens e mulheres;

- $\quad$ piadas sobre exército, polícia ou família;

- palavras estrangeiras ou grosseiras,

- músicas estrangeiras ou qualquer tipo de música que evoque prazer e alegria;

- mostrar de maneira positiva um personagem que prefira a solidão à vida coletiva;

- policiais e soldados malvestidos ou discutindo;

- mulheres vestidas indecentemente (as mulheres devem cobrir o corpo e o cabelo e não podem usar roupas justas ou coloridas) e maquiadas. (MELEIRO, 2006, p. 66).

O cinema iraniano, como um lugar de reflexo da cultura e de crítica aos acontecimentos históricos, parte de uma resposta social que, no interesse com o seu tempo presente, é também uma ferramenta ideológica, com outros 
pontos de vista sobre a sociedade. E mesmo com a censura, os cineastas tentam sempre, de alguma forma, demonstrar o real.

Shirin é um filme que apresenta um público no cinema que assiste à projeção de Khorrow e Shirin ${ }^{3}$, a tela do cinema não é vista pelo espectador, apenas o público assiste - público este composto apenas por mulheres. O espectador vê esse público, sendo as personagens as únicas imagens percebidas durante o filme.

\begin{abstract}
Apesar de desejar demonstrar o poder da história nos espectadores, Shirin não é obviamente uma ópera nem a realização daquilo que, historicamente, substituiu a ópera: o grande filme de cinema. Mesmo se também para Kiarostami, como para outros, depois da rarefação da história, produz-se um retorno ao segundo grau da potência operística do cinema, foi o caso, para ele, de contar uma história patética sem abandonar seu próprio cinema: de realizar ao mesmo tempo não o fazendo, fazer imaginar um grande filme sem o mostrar. (ISHAGHPOUR, 2016, p. 217-218).
\end{abstract}

Shirin se desenvolve, primeiro, pelo som off da projeção, que não se sabe se realmente ela acontece ali no momento ou se a projeção e o som foram colocados posteriormente à gravação, como um truque de montagem. Segundo, pelas faces de seus espectadores: as únicas imagens do filme.

É uma narrativa a questionar o real e a representação. Quando não há como saber se existe mesmo um público a ver uma projeção, ou se a mesma só existe na banda sonora, há então o questionamento das funções de manipulação/ encenação na homenagem ao cinema, feita pelo realizador. Shirin não questiona uma realidade social diretamente, algo que ocorre em Dez, mas questiona a função das histórias de ficção e a beleza do cinema como representação e reflexividade, seu papel de ópera e espetáculo, se utilizando da sala escura e do rosto das espectadoras para alcançar tal abordagem.

\title{
O lugar
}

O teórico Edward Said (2007), com seus estudos a respeito do Oriente Médio e principalmente sobre a construção do imaginário ocidental para o "Oriente", baseado no retrato imperialista que se fez das regiões orientais

3 Um antigo romance trágico da cultura persa. Khorrow e Shirin foi escrito por Nezami Ganjavi no século XII. Em suma, conta a história de amor entre o rei sassânida Khorrow II e a princesa Shirin. Há muitas versões de tal história na poesia e no romance persas. Antes ainda de Nezami Ganjavi, o poema épico Shahnameh (conhecido como O Livro dos Reis, espécie de lliada da mitologia iraniana), escrita por Ferdowsi no século X, já continha uma variante da tragédia Khorrow e Shirin. 
pela literatura, cinema, história e jornalismo, enxerga a visão ocidental aos territórios orientais como uma deturpação pejorativa e repleta de preconceitos e atravessamentos colonizadores na escrita da história. A isso Said chama de "orientalismos", toda sua obra de crítica literária e estudos sociais se volta para a construção das figuras orientais (com maior atenção ao povo árabe e palestino), como este movimento influenciou os conflitos políticos, a demarcação de fronteiras e a própria ideia de um Oriente Médio.

São muitas as questões que transformam e determinam uma área geográfica como lugar de múltiplos conflitos, não existe um único território no mundo que não tenha em sua história, até chegar nas delimitações de uma fronteira, os problemas para que esta exista. Mesmo já demarcado o território, as complicações culturais e políticas perduraram e ditam o comportamento de um lugar, que mesmo já considerado estabelecido, ainda sofre com as operações que o constituíram.

Território e fronteira são intervenções humanas na natureza que definem aspectos sociais e identitários dos povos do mundo, algo inerente desde a pré-história e uma das principais questões na organização da humanidade. A partir desse pensamento, se tem no Oriente Médio contemporâneo um espaço teórico para desenvolver a relação entre território e fronteira, e de que forma o cinema registra tal problemática. Através da linguagem, se inscreve nessa realidade, que resulta numa estética.

No filme Dez, as imagens partem para um retrato do Irã na proposta em que o diálogo em espaço único é matéria-prima para comentar a sociedade, o automóvel sendo o lugar onde prisões sociais são projetadas. E ao contrário de uma visão ocidental/orientalista, se vê uma sociedade comentando a si mesma.

A sociedade, nesse lugar em movimento, em que uma mulher dirige e conversa, enquanto a paisagem da janela vai e vem, está sob as leis drásticas do país. Assim, o Irã é abordado pela situação das personagens inseridas, tanto num espaço social quanto num espaço de confinamento (o automóvel).

Tal substituição da parte pelo todo, em que a atualidade iraniana é contornada numa única locação, coloca os passageiros desse carro num posicionamento crítico entre as demandas do cotidiano e costumes praticamente inabaláveis, ou seja, Dez é um filme social que ataca, a sua maneira, tais costumes ao colocá-los numa tensão entre passado e presente.

Quando um filme se propõe a investigar sua sociedade presente, e da estética se percebe um discurso, a imagem torna-se um campo político. Os 
filmes podem funcionar então como um comentário sobre a sociedade e um reestabelecimento espacial. Reestabelecer, portanto, é alterar o espaço, imaginá- lo para a tela, entrar em conflito com a realidade, circunscrevê-la, e assim problematizar suas estruturas.

Nas narrativas de Abbas Kiarostami, em especial aquelas que acontecem dentro de um automóvel, a construção social ocorre quando, sem sair de um local, se passeia por uma sociedade. Um filme como Dez, nesse caminho de ruas, é tão livre de sua sociedade quanto sujeito a ela. A legitimação do passado e uma possível autonomia para o futuro convivem no espaço do automóvel através dos atores que ali estão, e quando são postos entre liberações e sujeições sociais, através da representação da mesma, cria-se um confinamento espacial que serve à crítica.

"Um lugar é onde tudo começa, onde todas as viagens se iniciam" (MAGNO, 2010, p. 137). Em Dez, a sociedade aparece como um lugar dialógico, a viagem (ou trajeto), portanto, é um momento de reflexão através da conversação, uma espécie de comentário em movimento. São dez blocos temporais, narrativos e cotidianos, acontecidos dentro de um carro. Em cada bloco-sequência, uma mulher dá carona a personagens distintos. Tais personagens comentam, a sua maneira, o lugar de controle e suas relações com ele, em que um regime teocrático influencia diretamente no corpo e pensamento dos sujeitos.

\section{A crítica social}

As personagens em Dez são apresentadas de maneira propositalmente arquetípica ao conversar com a motorista: ora uma senhora conservadora e religiosa, ora uma prostituta, ora uma amiga com problemas matrimoniais ou o filho da motorista que introduz e conclui a história: sendo o primeiro e o último passageiro do carro.

O filho não aceita o divórcio de sua mãe e a culpa pela vergonha causada nele e em seu pai. Nesse jogo entre a criança e a mãe, a figura infantil, imbuída de um autoritarismo reiterado pelo estado e pela shaira ${ }^{4}$, é cônscia de que sua opinião é a verdade. Com exceção da criança, todas as personagens do filme são mulheres, usam véu e as conversas transitam por tópicos como a feminilidade, os direitos, a religião, a tradição e a sociedade atual (no caso o ano de 2002). 
O espaço provisório do automóvel é a representação social: a locação única torna-se, portanto, uma sociedade inteira discutida por mulheres iranianas, e assim, um espaço intelectual de mudança.

Em Dez, Kiarostami acoplou duas câmeras num carro em movimento, uma apontada para a motorista, outra para o passageiro [...], registrando continuamente, em fluxo ininterrupto, viagens e conversas que a montagem depois reorganiza, procurando manter a sensação de que assistimos a blocos do real inalterados. [...] Em tese, o cineasta armou o dispositivo e depois deixou que o real fizesse o resto. (OLIVEIRA JUNIOR, 2013, p. 11).

As prisões sociais sofridas pelas personagens são registradas por um método que aproxima ficção e documentário, alternativa perceptível na obra do realizador. Não há roteiro prévio, apenas uma intenção de história (motivações e linhas psicológicas pré-determinadas). Também não há a presença do diretor no set durante todo o tempo de gravação ${ }^{5}$.

O cenário é um carro em movimento, nunca filmado pelo lado de fora, com duas câmeras acopladas, uma em cada banco dianteiro (do motorista e do carona). Dez é basicamente um plano e contraplano dilatado onde só existe a preocupação em registrar o que se fala e o que se ouve, sem trilha sonora, sem raccord, sempre em primeiro plano ou close-up, utilizando-se de luz natural e som direto. É um plano e contraplano que não respeita a gramática da montagem clássica e se atém ao diálogo e aos momentos de silêncio. Daí a ausência de subterfúgios comuns da ficção e uma certa radicalidade. "A exclusividade de apenas dois ângulos, sem nenhum movimento nem alteração de enquadramento, e a exclusividade do espaço fechado - vamos dizer, o huis-clos do carro — só aparecem em Dez" (BERNARDET, 2004, p. 32).

\section{O enquadramento}

É possível dizer que há em Dez um esgotamento da decupagem clássica, mesmo que o sentido permaneça, pois num espaço de confinamento, quando há interação humana, as vozes querem ser ouvidas. É muito provável que essas mulheres, cobertas pelo hijab ${ }^{6}$, num dia quente, num ambiente

\footnotetext{
5 Abbas Kiarostami não estava presente no set, a atriz que representa Mania, protagonista que dirige o carro, usou um fone de ouvido escondido por baixo de seu lenço, e por ele ouvia a voz do diretor e seus apontamentos.

6 Véu utilizado pelas mulheres no Irã em locais públicos ou na presença de homens estranhos. Prática vinda de uma interpretação do Corão e reestabelecida no país após a queda do Xá, em 1979.
} 
íntimo e fechado mesmo que público, queiram falar - e falam o que não poderia ser dito em outros cenários. As personagens, presas ali, falam, já que o drama pede diálogos: daí um sentido permanente do clássico (em sua compreensão dialógica), embora seu esgotamento formal, com os dois ângulos utilizados do início ao fim.

Nota-se que os blocos temporais são separados por números, a começar com o número dez, daí em diante, regressivamente. É possível a hipótese da contagem regressiva ser relacionada com certo sentido de urgência, grito, ou algo a explodir. Faz-se em Dez uma estrutura temporal que, quase como esquetes (no melhor sentido do termo), está determinada ao tempo presente e um tempo de extremo controle.

Patrice Blouin comenta que Kiarostami inventou "a câmera de vigilância afetiva". Podemos até imaginar alguma correlação entre o uso desse tipo de câmera e o personagem principal de Dez. Kiarostami despoja essas câmeras de seu poder policial e as põe a serviço de Mania, que quer se ver livre da autoridade masculina - o que é coerente com a "eliminação" do diretor. (BERNARDET, 2004, p. 112).

O humano, sob o controle que em Dez acontece numa sociedade de profunda estatização da disciplina (no Irã, essencialmente fundamentalista religiosa) é, então, a câmera de vigilância afetiva de Abbas Kiarostami. Não uma vigilância de intimidade a controlar o corpo e o comportamento, e sim uma vigilância contrária a normas absurdas, que observa na sociedade uma deficiência e, afetivamente, dá vida e lugar de fala às personagens.

Filmado com câmeras digitais, possibilitando um enfoque íntimo na interação entre personagens e voltando-se do espaço exterior da paisagem para a vida das mulheres, o espaço interior do carro e a interioridade da emoção. (MULVEY, 2016, p. 160).

Mas não se pode, quando se observa o controle em relação à identidade das mulheres iranianas no filme, de forma íntima, como reconhecida por Mulvey, destituir a religião (e um arraigado senso comum sobre ela) desse controle. Pois seu indício e autorização, junto à vigilância e a modelos de disciplina, que carregam, e muito, quando há presença de um estado e religião uníssonos e unificados, uma forte compreensão de que o indivíduo e sua religião não se separam, e que o contrário inexiste, ou assim deve ser. 
O longo plano e contraplano que é o filme enquadra todas essas indagações e inadequações das personagens, que encerradas tanto no carro quanto no plano fílmico, precisam, ao menos, falar a respeito.

\section{A fala}

Os filmes de Abbas Kiarostami investigam o real, sua disposição e sugestão na relação entre ficção e documentário, atuação, fala e movimento pelo caminho (deslocamento) percorrido através das personagens de tais obras - seja a busca conduzida pelo carro ou uma travessia feita a pé.

Filmes como Vida, e Nada Mais... (Zendegi Va Digar Hich, 1992) e Onde Fica a Casa do meu Amigo? (Khane-ye Doust Kodjast?, 1987) são exemplos em que, por um caminho pré-determinado, a narrativa se afirma pelo trajeto a ser feito, a busca e finalidade das personagens (devolver um caderno ou encontrar uma pessoa, por exemplo) é também a busca pela história (o próprio filme) que se descobre e exibe suas propostas interessadas na captação poética de uma realidade social.

Já em Dez, tal caminho não segue a estrutura da busca; apesar de se saber que o carro vai a algum lugar, a chegada para tal lugar interessa muito pouco: estática num tempo presente enquadrado por um plano que praticamente não se modifica (um primeiro plano). Dessa forma, as personagens desenham o modelo social iraniano, acercadas por um confinamento móvel e única locação do filme: o carro dirigido por Mania (personagem protagonista). E ali, o que sobra para a exposição do meio social são a fala e a imagem da fala, o verbo como centro do registro fílmico.

Dez, compreendido esteticamente como um extenso plano e contraplano audiovisual, dividido em blocos, torna a fala uma evidência técnica. É através dela que se descobre o filme, aos poucos. A ideia da fala, nesta análise, então se divide por dois caminhos: a fala como procedimento de encenação e a fala como reflexo direto da cultura.

Sobre a encenação, se deve pensar que o cinema, na sua estrutura clássica, teve a fala como uma de suas principais abordagens. Ao pensarmos que um filme deve seguir a coesão temática da proposta, "do material, da trama, da ação, do movimento interno da sequência cinematográfica e de sua ação dramática como um todo" (EISENSTEIN, 2002, p.13), a conversação é, portanto, parte da técnica. A forma e o sentido do filme são muitas 
vezes prisioneiros da fala, o verbo como veículo temático revela tal forma e sentido: o filmar a conversa entre personagens.

Dentro da proposta de se filmar uma conversa, o cinema clássico contribuiu para a fala como centro da narrativa. Sentar e falar, levantar e falar, ou simplesmente colocar um personagem em frente a outro, sentados ou não, define até hoje a planificação fílmica.

\begin{abstract}
$\mathrm{Na}$ abordagem "levanta-e-fala", que pode se tornar "senta-e-fala", os personagens aparecem tomando posições, geralmente num plano-sequência. Um eixo de ação governa as orientações e linhas de olhar dos atores, e as tomadas, embora variadas em ângulo, são filmadas de um mesmo lado do eixo. Os movimentos dos atores são coordenados pelos cortes. A medida que a cena se desenrola, os planos tendem a se aproximar dos atores, levando-nos para o âmago do drama. A montagem analítica apresenta campo/contracampo, ângulos na altura dos ombros e planos únicos - tudo que se exige para seguir os códigos tradicionais da montagem da continuidade clássica. Quando os personagens mudam de posição dentro do espaço, aparece um novo plano geral para nos informar. (BORDWELL, 2008, p. 45).
\end{abstract}

Apesar da atenção à fala e a característica verbocêntrica do filme, Dez não se ocupa do registro clássico da fala, e sim o subverte ao explorar ao máximo as forças estéticas de um plano e contraplano. O que Abbas Kiarostami faz é alongar ao máximo a ideia de plano e contraplano e eliminar outros artifícios para a construção fílmica de captação dos diálogos.

A fala, aparente em Dez num espaço fundamentalista (e masculino), o Irã no caso, transposta ao cinema como lugar de discussão, e por ele admitida como central e urgente, é um significativo procedimento estético para as situações vivenciadas pelas personagens do filme.

Na verdade, qualquer que seja a enunciação considerada, mesmo que não se trate de uma informação factual (a comunicação, no sentido estrito), mas da expressão verbal de uma necessidade qualquer, por exemplo a fome, é certo que ela, na sua totalidade, é socialmente dirigida. Antes de mais nada, ela é determinada da maneira mais imediata pelos participantes do ato de fala, explícitos ou implícitos, em ligação com uma situação bem precisa; a situação dá forma à enunciação, impondoIhe esta ressonância em vez daquela, por exemplo a exigência ou a solicitação, a afirmação de direitos ou 
a prece pedindo graça, um estilo rebuscado ou simples, a segurança ou a timidez, etc. A situação e os participantes mais imediatos determinam a forma e o estilo ocasionais da enunciação. Os estratos mais profundos da sua estrutura são determinados pelas pressões sociais mais substanciais e duráveis a que está submetido o locutor. (BAKHTIN, 2006, p.116)

A forma (radical pela restrição de artifícios) tem na enunciação e na escuta - dentro do carro e dentro dos véus que cobrem a "fala" (no sentido de repressão) - , uma demonstração política de ordem íntima. São também as palavras que constroem o espaço, que nunca é descrito num plano geral e descritivo, por exemplo.

Imaginamos o meio urbano iraniano dentro de um carro pelos diálogos, e conseguimos, como espectadores, a imagem de um desenho social. A construção do espaço fílmico é dada pela fala, em que o locutor e o interlocutor, submetidos à situação social, descrevem o espaço do país, do cotidiano, da intimidade.

Na realidade, não são palavras o que pronunciamos ou escutamos, mas verdades ou mentiras, coisas boas ou más, importantes ou triviais, agradáveis ou desagradáveis, etc. A palavra está sempre carregada de um conteúdo ou de um sentido ideológico ou vivencial. É assim que compreendemos as palavras e somente reagimos àquelas que despertam em nós ressonâncias ideológicas ou concernentes à vida. (BAKHTIN, 2006, p. 96, grifo do autor).

É no registro de uma enunciação, que já se manifesta filtrada pelo meio e sujeita a ele, que Dez desenvolve, ao dar lugar (e poder) à fala das mulheres, sua estrutura narrativa. E essa narrativa são dois planos (a motorista e o carona) que são espaços de uma fala a reivindicar autonomia, mesmo que idealmente, por uma denúncia que é também afetiva.

Outro caminho para se pensar no poder da fala em Dez é através da cultura. A cultura é uma criação humana, resultado do trato com a natureza material e da luta por sobrevivência. Nesse processo, se estabelecem os conjuntos de técnicas adquiridas do mundo orgânico ao mundo social. É o que nos diferencia dos animais, uma produção a partir da existência, ao mesmo tempo que uma consciência de si mesmo. Junto a isso, é também uma necessidade de realização coletiva e domínio do mundo natural, a pensar uma relação produtiva com o ambiente (PINTO, 2020). A fala, dentro do 
campo da linguagem, é um dos instrumentos técnicos da humanidade, e por ela é possível a demonstração da cultura, portanto um bem de consumo (absorção das técnicas apreendidas) e um bem de produção (operação sobre o mundo).

As personagens em Dez, mesmo numa sociedade de extremo controle, se utilizam da fala, num espaço tanto público (carro em movimento pela cidade) quanto íntimo (o confinamento do automóvel a sugerir intimidade, segurança) para expressar algo sobre tal sociedade, principalmente no que diz respeito às mulheres. Essa utilização da fala expõe o saber das personagens, suas capacidades de crítica e sentimentos de inadequação. Ali, dentro do carro, a fala representa não apenas uma exposição dos sentimentos cotidianos, mas também a voz como um bem de consumo e de produção, pois é pelo diálogo com a motorista que as passageiras discutem dogmas sociais e mostram sua existência, fazem parte da cultura e tentam, apesar das leis, uma consciência de seus próprios valores.

Contudo, uma das problemáticas da cultura é a alienação. No filme tal questão é aparente no personagem do filho da motorista, que, como já mencionado, é o único personagem masculino do filme e ocupa os espaços do primeiro e do último bloco da narrativa. Entre todos os passageiros que aparecem no carro, a criança é quem usa a fala como instrumento autoritário, a repetir os dogmas e as proibições da sociedade iraniana. É uma fala que ratifica a cultura social, que não a problematiza. Daí a alienação, ou seja, não entender que o humano é um bem de produção. Se produz cultura por uma necessidade existencial e, ao invés do ser humano se apropriar da cultura, ele a considera superior, algo que não faz parte dele, e, portanto, aliena-se, repete e segue sem pensamento, tornando-se um produto do meio ao invés de ser uma existência produtiva do meio.

Quando dizemos que o homem é um bem de produção queremos entender com isso que deve ser um bem de produção de si mesmo, para si mesmo, ou seja, que sua ação sobre a realidade deve ser utilizada apenas em benefício de cada homem, para torná-lo mais humanizado na sua compreensão do mundo e nas relações com os semelhantes. Se, porém, como de fato acontecerá, o homem se torna um bem de produção não para si exclusivamente, mas para outro, e, portanto, se converte em instrumento de utilização alheia, desaparece a dignidade que o caracterizava como produtor de si mesmo pela mediação da cultura que fora criando e acumulando, e se estabelece um regime de convivência injusto e desumano. (PINTO, 2020, p. 132). 
Portanto, o filme se utiliza da fala (numa radicalidade em relação ao clássico) e a coloca no lugar da cultura. Essa localização se dá por duas formas: uma é através do sujeito ativo à cultura, que produz um pensamento apesar do controle (no filme é o papel das mulheres); e outra forma é através do sujeito alienado, que apenas reitera o pensamento do meio, sem propor mudanças e a funcionar como um sintoma, ou seja, a alienação.

\section{O meio}

Se a fala é um reflexo direto da cultura, esta só se realiza com a existência do meio. Como já descrito, em Dez o lugar está em movimento, mas está preso, encadeado em dez momentos que no conjunto constituem o filme. Cada personagem, com sua voz, descreve um estado psicológico em ocorrência do espaço físico e do meio social: tanto um espaço de sociedade conflitante entre tradição e mudança, materialidade e fluxo; quanto um cotidiano particularizado e de liberdades controladas.

Os planos se demoram e as personagens falam; nesse cinema predisposto por Abbas Kiarostami não há grandiloquência, mas sim o recorte do cotidiano como a categoria do todo. Pode-se conceituar tal recorte por vários caminhos: é uma análise social; é uma demonstração da cultura que se relaciona com um espaço economicamente globalizado e socialmente preso a tradições de controle de ordem religiosa; e é um método de representação na confluência entre a restrição das imagens (pelo regime e seu regulamento) e as imagens constituintes do objeto artístico (o próprio filme).

Pode-se, pois, imaginar que um espaço tenderá tanto mais a se tornar um espaço racional quanto mais alto for nele o nível de artifício. O que comumente se chama de "espaço de fluxos" na realidade não abrange todo o espaço. Trata-se, na realidade, de um subsistema, formado por pontos ou, no máximo, linhas e manchas, onde o suporte essencial são os artefatos destinados a facilitar a fluidez e autorizar o movimento dos fatores essenciais da economia globalizada. É, aliás, comum que essa noção, aceita como abrangente - mas que na verdade é restrita — de um espaço de fluxos, venha frequentemente acompanhada de uma outra noção, a noção de homogeneização. 0 caráter invasor, hoje, da técnica atribui aos recortes verticais do território uma vocação de possessividade, mas o governo das ações dependentes se dá através de pontos ativos que reinam sobre planos heterogéneos. Tais ações buscam adaptar-se a esses planos heterogéneos, sobre os quais impõem uma ordem, mas sem alterar sua heterogeneidade. (SANTOS, 2006, p. 201). 
Dez, ao perpassar o espaço urbano do seu país através do automóvel, também aprofunda as noções sobre o meio quando coloca, num tempo atual, o modo de vida das personagens desse país (que é um espaço do mundo).

Através dos conceitos entrelaçados do geógrafo Milton Santos ${ }^{7}$, é possível avaliar Dez como a representação de uma natureza social dentro de um espaço de extensão política e geográfica. São as imagens do meio urbano, vistas apenas num espaço único, o automóvel. Mas é um espaço que, mesmo no campo semântico do confinamento, está em movimento.

\section{O deslocamento}

As personagens estão confinadas, passageiras de um carro e de uma política vigente, mas há a reiteração da ideia de deslocamento. A essa ideia podese pensar numa estética de deslocografia, e não apenas de confinamento.

\footnotetext{
Sendo assim, a deslocografia constrói a paisagem que é "tudo aquilo que vemos, o que nossa visão alcança", "definida como o domínio do visível" e não "formada apenas de volumes, mas também de cores, movimentos, odores, sons". [...] Cada personagem, em seu deslocamento, ainda que centrado no objetivo de sua busca, desenvolve relacionamentos em seu percurso, que, por sua vez, compõem a própria temática das narrativas em desdobramento. (GOSCIOLA; MAGNO, 2011, p. 11).
}

O meio (onde as personagens vivem e se movimentam) apresenta, portanto, uma atualidade espaço-temporal do país dentro de um mundo globalizado e com os problemas políticos que o definem (externa e internamente). Se todo país inserido num comportamento globalizado - e acometido por ele, devido a técnicas socioeconômicas para organizá-lo, chamando assim de um espaço de fluxo - é também definido por métodos coercitivos (dos governantes); um filme que o revela (o país, o método, as formas sociais) torna-se uma ideia crítica de espaço-tempo de tal território, e também uma atmosfera de deslocografia, visto que os personagens mesmo presos, estão em movimento pelos lugares da cidade.

Para esclarecer, a técnica se dá em sistemas: a inserção de uma atrai outras. Porém, ao mesmo tempo, há convivência de técnicas de diferentes tempos,

7 Na etapa amadurecida de sua teoria, em que tais conceitos são híbridos ou pares dialéticos: a verticalidade e a horizontalidade, a materialidade (como produto das técnicas mediadoras entre os homens e os objetos) junto às ações, o passado e o presente. 
deixando de haver a fluidez dos fluxos e, com isto, diferenciando os lugares. Todas as redes, verticalidades e horizontalidades, são fluxos (coisas e ideias) e fixas (materialidades).

Propomos o conceito deslocografia para identificar o modo como o cinema discute: as sociedades e os territórios imaginados sejam lineares ou complexos; as coletividades geradas por sentimentos em comum; as imagens e sons definidores de novas coletividades; os territórios construídos pelos sentidos; o nomadismo contínuo como território articulador de sociabilidades. (GOSCIOLA; MAGNO, 2011, p. 2).

A referência à deslocografia, abordada pelos autores Vicente Gosciola (2011) e Maria Ignês Carlos Magno (2010), feita no registro e representação dos atores, no caso as personagens-passageiras, aborda então as técnicas de uma cultura e modo econômico do meio espacial das mesmas: é feito o recorte de um tempo e de um espaço pelas figuras humanas que servem a este recorte.

A questão do tempo e da materialidade do espaço deve ser estudada pelo problema técnico. As técnicas é que trazem a definição de materialidade. Exagerando, diríamos que até a própria natureza poderia ser estudada do ponto de vista técnico - é um certo exagero, licença poética. E o evento, que é a sociedade, vai se encaixando nesses objetos. Temos então, de um lado, o tempo das ações e, de outro, o tempo da materialidade. É assim que penso na associação das noções "de tempo e espaço". As ações são uma possibilidade vaga ou concreta oferecida por um momento preciso da história - as ações que eu posso realizar hoje não são as mesmas que eu poderia realizar há vinte anos, as ações são datadas. Mas a oportunidade é que faz com que a possibilidade se torne concreta, e é dada pela materialidade que, cada vez mais, é um produto da elaboração técnica. Esta seria a "chave" para uma epistemologia da geografia atual. Haveria os objetos que são o tempo cristalizado, mas que terminam tendo um papel de controle do tempo das sociedades. Porque eu não faço o que quero deste ou daquele objeto, mas é ele quem, afinal, vai decidir o que faço dele. Então esse encontro é que se dá via evento. Porque o evento é a oportunidade, é um fato gerado por uma dinâmica histórica que encontra a sua vez em um lugar definido através de formas que hoje são extremamente variadas. (SANTOS, 1994, p. 91). 
Para simplificar, o que se quer definir é a exposição do conteúdo fílmico como um desenho de sua sociedade, economia e cultura dentro de uma representação. Esta, de uma natureza social, inclui sua história, a cingir também o modelo econômico e a forma de governo dessa natureza (os objetos técnicos; no caso, lidos de modo vertical, não só determinados por governo e economia).

\section{A natureza social}

Natureza social aqui pode ser uma expressão redundante. A natureza primeiramente se transformou nas materialidades do espaço geográfico, trabalhada pela técnica, cujo desenvolvimento e incorporação não se dá com uniformidade, mas em verticalidades — sem necessariamente a contiguidade: é a "empirização" do tempo, referida por Milton Santos. Por isso redundante, contudo, uma expressão utilizada nesse texto visto que toda natureza é social desde que o homem se separou da primeira natureza, tomando-a como sua num processo de técnicas.

Como Dez é um filme iraniano do século XXI, mesmo que traga a avaliação de tradições milenares, algumas incorporadas na pós-revolução de 1979 (como a volta dos códigos de vestimenta), também traz nessa avaliação, interpretações contemporâneas, de um presente global, portanto:

Kiarostami, pelo contrário, enveredará cada vez mais, com um filme como Dez (2002), por um cinema em que a pessoa filmada será tão importante quanto o cenário inicial, se não mais, e em que a sua personalidade, o seu próprio ser, vai se tornar a principal matéria-prima do filme. (BER-

GALA, 2016, p. 111).

No confinamento do automóvel é o espaço cultural que se movimenta (a natureza humana), e isso dá voz a quem pode ser preso se protestar, dá corpo a novos problemas de uma nova sociedade e, por blocos em contagem regressiva, a partir do numeral 10, instaura sua emergência.

\section{O confinamento}

Para o estudo crítico dos filmes aqui abordados, espaço e representação são conceitos trabalhados e retomados: um espaço de confinamento em que atua a narrativa a formar imagens e, por essa representação, o espaço de extensão e seus fluxos acercados. 
Aqui, o interesse reside no indivíduo e sua interpretação de uma cultura (e sociedade) através do audiovisual. Dez é um exemplo de tal interpretação (também manipulação e uma forma de artifício: o cinema) de natureza construtiva (ideológica, por certo) na sua observação de uma realidade observação esta contrária a prisões sociais.

Shirin, como descrito, discute o teor dessas encenações e manipulações a partir do cinema como artifício de exposição, porém nele não há deslocamento. Enquanto Dez serve à noção de deslocografia em confinamento, Shirin faz um desenho no qual o que se vê só pode ser imaginado na mente do espectador, que imagina o filme a que os personagens assistem, é talvez uma estética antideslocográfica.

Mas é em Dez que Abbas Kiarostami, pelo artifício fílmico, coloca tal manipulação a favor do esclarecimento de prisões sociais (em movimento). As restrições em cima de um filme iraniano, transfiguradas em radicalismo formal (um automóvel como locação e dois planos), mostram o modelo social como campo de ação de tais prisões, a evidenciar aquilo que a própria política de restrição tentou evitar. Dez é a imagem de confinamentos sobre o confinamento maior: as leis do estado

No Irã, há limitações impostas pelo regime. Eu as conheço, sei o que posso mostrar e aprendo a trabalhar dentro dos limites. No meu país, a luta contra essas restrições é uma fonte de energia. Nós, iranianos, vivemos apesar de tudo. Até mesmo as jovens proibidas de mostrarem seus cabelos também encontram uma maneira para que uma mecha de escape ao lenço. Se você vai a Teerã poderá ver nas ruas muitas pessoas que fazem mais do que está permitido, mesmo que isso seja apenas deixar uma mecha de cabelo à mostra. (KIAROSTAMI, 2014, p. 11, tradução nossa).

A imagem é, portanto, representação; seu caráter de manipulação do real não é uma alternativa, e sim sua essência, e alternativa do uso de tal manipulação para construir uma realidade. Esta pode ser tanto uma propaganda totalitária quanto argumentos contrários a uma situação histórica (em Dez, no caso, o tempo presente) preocupados com o movimento das ideias e da sociedade.

Tal movimento não é aqui considerado um avante em linha reta, como um discurso desenvolvimentista e nacionalista de mudança social. O movimento, no sentido de percepção das sociedades onde se tornam visíveis voz, corpo e pensamento dos indivíduos e dos espaços por caminhos multiformes, 
para conhecê-los e entendê-los em suas prisões, confinamentos, utopias e manifestações políticas, sociais e estéticas.

Para aprofundar o debate sobre o automóvel e seus sentidos, se faz necessária uma última exposição do problema.

Primeiro, o confinamento, na sua dramatização, gera poder de fala através das personagens. A fala, portanto, como uma das expressões da linguagem, é ferramenta - para o cinema persa aqui recortado - de exibição da sociedade. Ou seja, o que o espaço fílmico não mostra por se encerrar numa paisagem de confinamento, a fala revela.

Segundo, a forma obtida no registro cinematográfico, que relaciona espaço físico e dialógico é uma narrativa social, fílmica e histórica. Do mesmo modo que a escrita da história é uma narrativa que relaciona a linguagem escrita com as ações da história. Então, o cinema, como parte de uma linguagem, dentro de um campo estético, também é um produto histórico.

Tal produto histórico (o filme) é uma forma de texto. Se existe um cinema social (apesar de que qualquer filme é social a partir da leitura que dele se faz), ele é assim considerado por reinterpretar sua sociedade. Os conceitos e contextos que um filme carrega são, então, interpretações históricas (no espaço-tempo), reestabelecidas pela estética e pela filosofia (de certa forma a própria história e os conceitos de sociedade também o são).

A interpretação espacial e social, a partir da linguagem foi, até agora, uma abordagem possível na observação do Irã contemporâneo através dos filmes de Abbas Kiarostami. Não é o único caminho, contudo; entender as características de uma prisão social — na fisicalidade de uma infraestrutura determinada pelos aspectos de uma superestrutura (o poder religioso, a política, por exemplo) e usar o cinema como objeto - auxilia no aprofundamento das noções de representação e manipulação: que dão origem a uma ideologia e, por ela, um retrato social.

Tais prisões (confinamentos) podem aparecer de muitas maneiras e se localizam em distintos espaços e graus de ação. Pelo automóvel se estabeleceu a forma social do confinamento, por ser este um símbolo moderno (e contemporâneo) e em trânsito nas disposições de uma cidade; e por ser um espaço de confinamento num movimento urbano, em deslocamento. Também outro espaço de crítica é a própria sala de cinema, evidenciada pela análise do filme Shirin. 


\section{Consideração final}

Abbas Kiarostami, através das locações aqui discutidas (o automóvel e a sala de cinema), faz de tais espaços um resultado cinematográfico radical, frente às objeções, onde imagens sociais ausentes por restrições são aparentes pela captação individualizada das personagens ali "presas”. Tal formulação teórica se desdobrou para a impossibilidade de captação de uma realidade total pelo cinema e a forma que esta impossibilidade traz às realizações audiovisuais do cineasta, onde ele vai pensar em espaços únicos para o registro de sua sociedade. Nesse registro, o artigo apresentou algumas temáticas/ ideias a respeito de Abbas Kiarostami.

O filme Dez é dividido em dez blocos e o presente trabalho partiu da mesma formulação, pois escolheu dez temas para analisar a obra do realizador (em especial os filmes Dez e Shirin) para entender pontos de encontro entre cinema e sociedade, a partir de um jogo paramétrico que faz alusão ao título do filme e também a sua estrutura.

Os conceitos propostos vislumbram a capacidade de fortuna crítica que o cinema de Abbas Kiarostami representa à comunicação audiovisual e aos estudos de cinema. Portanto, foram separados alguns conceitos em detrimento de outros, e é óbvio que não existem apenas dez ideias. Estas foram colocadas por uma questão estilística de acordo com a proposta metodológica adotada: o jogo textual entre o filme Dez e os dez pensamentos dispostos no texto.

\footnotetext{
Jansen Hinkel é doutorando pelo Programa de PósGraduação em Comunicação da Universidade Anhembi Morumbi, é mestre em Comunicação pela mesma instituição e possui graduação em Cinema e Vídeo pela Unespar.

hinkeljansen@hotmail.com
}

\section{Referências}

AUMONT, J. A estética do filme. Tradução: Marina Appenzeller. 9a Edição. Campinas, SP: Papirus, 2012.

BAKHTIN, M. Marxismo e Filosofia da Linguagem. 12a Edição. São Paulo: Hucitec Editora, 2006.

BERGALA, A. “Da epifania no cinema de Kiarostami e Rossellini”. In: Um filme, cem histórias: Abbas Kiarostami. Brasília, Rio de Janeiro, São Paulo: Centro Cultural Banco do Brasil, 2016, p. 109-117. 
BERNARDET, J.-C. Caminhos de Kiarostami. São Paulo: Companhia das Letras, 2004.

BORDWELL, D. Figuras Traçadas na Luz: a Encenação no Cinema. Tradução: Maria Luiza Machado Jatobá. Campinas: Editora Papirus, 2008.

EISENSTEIN, S. O Sentido do Filme. Tradução: Teresa Ottoni. Rio de Janeiro: Jorge Zahar Editor, 2002.

ISHAGHPOUR, Y. "A alma do Irã. Sobre Shirin de Abbas Kiarostami". In: Um filme, cem histórias: Abbas Kiarostami. Brasília, Rio de Janeiro, São Paulo: Centro Cultural Banco do Brasil, 2016, p. 211-224.

KIAROSTAMI, A. Los Caminos de Abbas Kiarostami. Buenos Aires, Argentina: Fundación PROACINE, 2014.

MACHADO, A. A Desmontagem Do Dispositivo Cinematográfico. In: MORAN, Patrícia. (Org.). Cinemas Transversais. São Paulo: lluminuras, 2016.

MAGNO, I. C. Nas narrativas que atravessam as paisagens do sertão: um estudo sobre o cinema construindo o imaginário em processo. Comunicação e Educação (USP), v. ano XV, 2010, p. 131-142.

MELEIRO, A. O Novo Cinema Iraniano: Arte e Intervenção Social. São Paulo: Escrituras Editora, 2006

MULVEY, L. "Abbas Kiarostami: cinema de incerteza, cinema de atraso". In: Um filme, cem histórias: Abbas Kiarostami. Brasília, Rio de Janeiro, São Paulo: Centro Cultural Banco do Brasil, 2016, p. 141-160.

GOSCIOLA, V.; MAGNO, I. C. A construção do imaginário em deslocamento: um estudo da descolografia no sertão do cinema brasileiro. In: RAZÓN Y PALABRA Primera Revista Electrónica en América Latina Especializada en Comunicación. México: 2011.

OLIVEIRA JUNIOR, L. C. A mise em scène no cinema: do clássico ao cinema de fluxo. Campinas: Papirus, 2013.

PINTO, A. V. Ciência e Existência: problemas filosóficos da pesquisa científica. Rio de Janeiro: Contraponto, 2020.

TUAN, Y. Espaço e lugar: a perspectiva da experiência. São Paulo: Difel, 1983.

SAID, E. W. Orientalismo: o Oriente como invenção do Ocidente. Tradução: Rosaura Eichenberg. São Paulo: Companhia das Letras, 2007.

SANTOS, M. A Natureza do Espaço: Técnica e Tempo, Razão e Emoção. $4^{a}$ Edição. São Paulo: Editora da Universidade de São Paulo, 2006.

. Técnica, Espaço, Tempo: Globalização e meio técnicocientífico informacional. São Paulo: Hucitec Editora, 1994.

Artigo recebido em 23/10/2020 e aprovado em 07/05/2021. 